\title{
Study of Impact on Undergraduates' Entrepreneurial Failure based on the Model of Psychological Resilience-Knowledge Acquisition
}

\author{
Tang Jing ${ }^{1,2}$, Luo Dancheng ${ }^{1} \&$ Zhao Ye ${ }^{1}$ \\ ${ }^{1}$ Guangdong University of Foreign Studies, City Guangzhou, China \\ ${ }^{2}$ Reseach center for international Trade and Economic, China \\ Correspondence: Tang Jing, School of Economics and Trade, Guangdong University of Foreign Studies, China. \\ Tel: 1-372-536-3206. E-mail: lindatang_303@163.com
}

Received: March 29, 2016 Accepted: July 4, 2016 Online Published: July 5, 2016

doi: 10.5539/elt.v9n8p224 URL: http://dx.doi.org/10.5539/elt.v9n8p224

\begin{abstract}
Purpose-The entrepreneurship is a course of gaining knowledge from the failure and stimulating positive energy constantly. The entrepreneur's psychological resilience is the key to gain knowledge (positive energy) from failure (negative energy). The education of undergraduate entrepreneurship is one of the priorities these days. Educators shall transform from "success education" to "failure education", and combine entrepreneurial failure education with positive resilience cultivation. Through the approach of field interview, this thesis examines the impact of student entrepreneurs' resilience after failure on knowledge acquisition and subsequent success. As a result, a learning model of student entrepreneur after business failure is discovered, which offers a practical point of reference for undergraduates' entrepreneurship education today.
\end{abstract}

Keywords: positive psychological capital, entrepreneurial failure, knowledge acquisition, psychological resilience

\section{Key Point of Undergraduate Entrepreneurship Education: Transformation from "Success Education" to "Failure Education"}

Startup is an important impetus for economic and social development as well as the effective path to create new jobs. However, no matter in China or abroad, in mature markets or economics in transition, entrepreneurial failure rate is very high. Regarding the function of educating and developing talents, higher education institutes shall position the "entrepreneurship education" with focus on "innovative talent cultivation", so as to develop "talent with innovation value, spirit and ability who works on innovation and makes contribution to society". Therefore, entrepreneurship education should be combined into the cultivation of high quality and all-developed talents at universities, which as well, requires the close link between innovation value and entrepreneurial practice. As the rate of successful startup is generally low, undergraduates confront with more failure than success and business failure is an inevitable topic in the entrepreneurship education. Meanwhile, the business startup process in social reality, to a large extent, is a trial of psychological capacity and the previous failures shadow most surviving student entrepreneurs (Timmons, 1990). The value of "failure is not an option" makes a large number of people turn a blind eye to the entrepreneurial failures (Husted \& Michailova, 2002). Moreover, the research topics are mostly themed by the personality traits of successful student entrepreneurs rather than discussing the continuous success after failures. How to handle and confront the frustration and failure appropriately is the crucial course of undergraduate entrepreneurship education (Shepherd, 2003). If lack of failure experience, undergraduates will have the least capacity to handle the changing external environment, that is to say, a lack of resilience (Douglas \& Widavsky, 1982). Accordingly, this study starts from the perspective of resilience in positive psychology, to observe the students' recovering from failure and learning process, with the hope to strengthen the width and depth of the study on undergraduates' entrepreneurship.

\section{Key Role of Resilience to Knowledge Acquisition after Entrepreneurial Failure}

Academically, the study of entrepreneurship education is in a very early phase and its rationales are based on economics, psychology, sociology and other disciplines. The early economics is mainly exploring the role of startup in economic development as well as its industrial contribution. Overall speaking, the study of entrepreneurship in the area of economics lacks of representative theory schools and foundation (Arend, 2003). 
Until the recent years, the understanding of the essence of startup activities are further deepened, with the attention shifted from behavior rationality of startup process (how to succeed) to cognitive rationality of entrepreneurs (how to perceive and decide). The study can't simply focus on the regularization and standardization of startup process. Based on the structure of "scenario-thinking-behaving", the thesis explores how the scenario affects the process of undergraduates' cognition and decision during the startup, causing the difference of behavior and outcome.

The student entrepreneur community is large, widespread, flexible, highly-open and spread fast. They are the emerging force of the massive startups in the new age. Most successful student entrepreneurs have experienced failures, which introduces a basic question - why some of the startups are able to learn from the failure and crowned with success in the end? After all, when the entrepreneurs are seeking for success, they are careful to avoid being defeated and attempt to learn from the mistakes in the process (March \& Shapira, 1987). The study questions in this thesis are as the following: how does the subjective emotion rising from entrepreneurial failure evoke the students to learn and reflect? As the entrepreneurship educators, how should we guide the students to understand the startup failure?

\section{Effect and Mechanism of Positive Psychological Capital on Knowledge Acquisition after Entrepreneurial Failure}

By adopting the research approach of narratives, Byrne and Shepherd (2015) discovered the emotion is the key factor that affects the entrepreneur to make sense of the failure event. The emotional recovery is the essential prerequisite of acquiring knowledge and rethinking after failure. Therefore, positive psychological capital is of great significance to startup failure.

\subsection{Positive Psychological Capital Model}

Luthans (2004) introduced that the corporate competitive advantage should transfer from traditional economic, human and social capital into psychological capital. In contrast to Human Capital of "what you know" (Van Marrewijk \& Timmers, 2003) and Social Capital "who you know" (Adler \& Kwon, 2002), positive psychological capital is not only concerned with "who you are", but also, in the developmental sense "who you are becoming" (Luthans \& Youssef, 2004). Psychological capital is defined as the positive and developmental state of an individual as characterized by high self-efficacy, optimism, hope and resiliency. These positive psychological capacities are measurable, open to development, and manageable (Luthans et al., 2007).

In 2007, Luthans developed the famous PsyCap Intervention (PCI) training model, which is the development aid to improve positive psychological capital and actively affect the organization in the end. The model is as below:

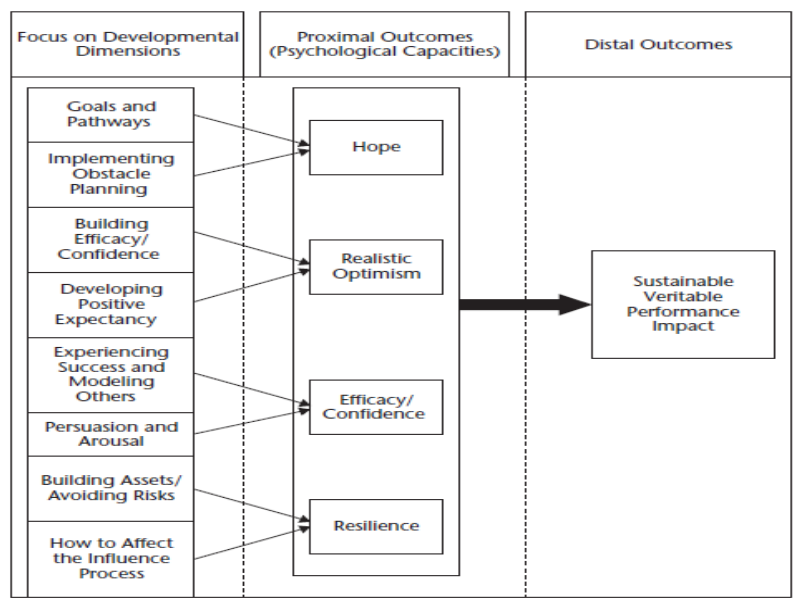

Figure 1. Positive PsyCap Intervention adapted from Luthans, Youssef, and Avoil (2007)

Positive psychology has diverted the research from the defect mode of dangerous and negative factor to the individual's strength and advantage. The purpose is to develop the positive capacities that facilitate the individual growth. One of them is resilience, which is defined as a positive way of coping with adversity. When the individual is confronting the adversity and distress, the study of resilience has become the key issue of positive psychology. Failure is of great significance to the subsequent success (Shepherd, 2003; Cardon et al., 2011). Based on the perspective of resilience in positive psychology, we will discuss on how to restore from the 
entrepreneurial failure for the students and how to learn from the failure.

\subsection{Mechanism of Resilience on Entrepreneurial Failure}

The proposal of the resilience concept was in the study of children in Kauai Island by two scholars Werner and Smith. According to the definition in Webster Dictionary, resilience is an ability to recover from or adjust easily to misfortune or change. It is also a force (Richardson, 2002) that drives a person to grow through adversity and disruptions. Or when beset by problems and adversity, one is able to sustain and bounce back and even beyond (Luthans \& Youssef, 2004).

The role of resilience in coping entrepreneurial failure mainly includes three aspects, which are interpretation of adversity, coping ability in adversity and process of recovery. To student entrepreneurs, resilience is the most important personal ability, which is the combination of efficacy and confidence, strong interpersonal network and support. Even after the business loss, the students are able to learn managing the emotions, restoring the mind and strengthening the mental positivity. The actions taken during the process of recovery are how the students make the sense of learning, recovering from failure and go beyond. Resilience is the trait of the student's ability, as well as the process when students interacting with the external environment. The undergraduates with resilience are usually able to recover to the steady state quickly from stressful encounters, learn from the failure and strengthen the adaptability to the environment (Seibert, 2009). When confronted with problems in the new venture, undergraduates with high resilience are more likely to adopt positive attitude, consciously make relentless efforts and persevere with the established goals and adapt to the changes by the goals and behaviors, so as to conquer the difficulties and realized the desired goals.

To sum up, the entrepreneurial resilience possessed by the undergraduate mainly refers to the perseverance and no fear to achieve the intended goal, and the unity of self-recovery and self-transcendence.

\subsection{Influence of Resilience on Undergraduates' Entrepreneurial Failure}

Entrepreneurial failure is a common occurrence to every startup. But resilience of different attributes would lead to different learning modes from failure experience. The study is focused on the entrepreneur's change of the mental model in the process of learning after failure, which enables each individual to realign the expectation for startup and self and reflect on themselves. This is significant to the failure experience of new venture and it is also the complicated course of generating knowledge regarding new venture creation.

The failure is the experience gained for subsequent business success, which has practical value. However, according to the study by Husted (2006), suffering from failures, individual is not willing to share the knowledge learnt from the experience, fearful of the blame or punishment by the business partner. Shepherd considers "recovery from entrepreneurial failure" includes "learning from the failure" and "commitment to the subsequent venture creation". Failure provides the entrepreneurs with the key learning to the subsequent success (Shepherd, 2004). It was found that whether the first-time entrepreneur is able to "learn from failure" relies on how they recover from negative emotions. It is furthered proposed that a frame of learning from failure needs to be established to observe how to put failure to work to innovate (Cannon \& Edmondson, 2005). But for individual, how to learn from failure? The study targets at the individual of student entrepreneurs experiencing failure and explores how to learn in the innovative and creative activities, with the focus on how to recover and gain knowledge. It attempts to construct the learning framework of the students after business failure.

\section{Method and Object of Research}

Semi-structured interview is adopted for the research and each case is analyzed. Process research is the approach to study the resilience capacity of the student and recovery after entrepreneurial failure, in hopes of providing effective way to the educators. 


\begin{tabular}{|c|c|c|c|c|c|}
\hline Objective & Study & $\begin{array}{l}\text { New Venture } \\
\text { Creation }\end{array}$ & $\begin{array}{l}\text { Operation } \\
\text { Crisis }\end{array}$ & Low Tide & Bounce-back \\
\hline $\begin{array}{l}\text { HUANG,XX } \\
\text { (Male) }\end{array}$ & $\begin{array}{l}\text { Outstanding } \\
\text { academic } \\
\text { results }\end{array}$ & $\begin{array}{l}\text { Start to succeed } \\
\text { and develop }\end{array}$ & $\begin{array}{l}\text { Receive little } \\
\text { attention from } \\
\text { team members }\end{array}$ & $\begin{array}{l}\text { Different belief } \\
\text { from the partner }\end{array}$ & $\begin{array}{l}\text { Make efforts to } \\
\text { gain the leading } \\
\text { position on the } \\
\text { team again }\end{array}$ \\
\hline $\begin{array}{l}\text { ZHAN, XX } \\
\text { (Male) }\end{array}$ & $\begin{array}{l}\text { Organize } \\
\text { campus events } \\
\text { and lead the } \\
\text { school club }\end{array}$ & $\begin{array}{l}\text { Establish studio } \\
\text { and organize } \\
\text { large events }\end{array}$ & $\begin{array}{l}\text { Lack of } \\
\text { regulation and } \\
\text { management }\end{array}$ & $\begin{array}{l}\text { Different attitude } \\
\text { towards capital; } \\
\text { leaving of core } \\
\text { member; finance } \\
\text { deterioration }\end{array}$ & $\begin{array}{l}\text { Meet new } \\
\text { partner and find } \\
\text { the } \\
\text { entrepreneurial } \\
\text { impetus again }\end{array}$ \\
\hline $\begin{array}{l}\text { LIU, XX } \\
\text { (Female) }\end{array}$ & $\begin{array}{l}\text { Work on the } \\
\text { startup team }\end{array}$ & $\begin{array}{l}\text { Steady growth } \\
\text { with } \\
\text { performance; } \\
\text { become a boss }\end{array}$ & $\begin{array}{l}\text { Lack of } \\
\text { leadership, } \\
\text { management } \\
\text { experience } \\
\text { leading to } \\
\text { crisis }\end{array}$ & $\begin{array}{l}\text { Can't cope with } \\
\text { negative emotions }\end{array}$ & $\begin{array}{l}\text { Meet a mentor, } \\
\text { realign the mind } \\
\text { with positivity }\end{array}$ \\
\hline $\begin{array}{l}\text { WU, XX } \\
\text { (Female) }\end{array}$ & $\begin{array}{l}\text { Enter the } \\
\text { enviable } \\
\text { Entrepreneur's } \\
\text { Park and have } \\
\text { excellent } \\
\text { performance }\end{array}$ & $\begin{array}{l}\text { Like to innovate; } \\
\text { start a sports } \\
\text { equipment } \\
\text { company with } \\
\text { senior } \\
\text { schoolmate and } \\
\text { start to gain profit }\end{array}$ & $\begin{array}{lr}\text { Not familiar } \\
\text { with } & \text { sales; } \\
\text { dispute } & \text { with } \\
\text { partner } & \end{array}$ & $\begin{array}{l}\text { Operation crisis; } \\
\text { self-isolation; } \\
\text { disappointment with } \\
\text { startup }\end{array}$ & $\begin{array}{l}\text { Help from good } \\
\text { friend; transform } \\
\text { to clothing } \\
\text { business on } \\
\text { campus }\end{array}$ \\
\hline $\begin{array}{l}\text { CHEN, XX } \\
\text { (Female) }\end{array}$ & $\begin{array}{l}\text { Poor academic } \\
\text { results }\end{array}$ & $\begin{array}{l}\text { Follow the family } \\
\text { to start new } \\
\text { business; strong } \\
\text { desire of business } \\
\text { creation }\end{array}$ & $\begin{array}{l}\text { Leadership } \\
\text { crisis; } \\
\text { management } \\
\text { crisis }\end{array}$ & $\begin{array}{l}\text { Thorough } \\
\text { rethinking on } \\
\text { entrepreneurship; } \\
\text { self-reflection }\end{array}$ & $\begin{array}{l}\text { Find confidence } \\
\text { again; adjust the } \\
\text { attitude }\end{array}$ \\
\hline $\begin{array}{ll}\text { MO, } & \text { XX } \\
\text { (Male) } & \end{array}$ & $\begin{array}{l}\text { Joint three } \\
\text { different } \\
\text { school clubs }\end{array}$ & $\begin{array}{l}\text { Raise funding for } \\
\text { startup; } \\
\text { underestimate the } \\
\text { technical problem } \\
\text { and trap into } \\
\text { crisis }\end{array}$ & $\begin{array}{ll}\text { Struggle } & \text { with } \\
\text { academic } & \\
\text { study } & \text { and } \\
\text { startup } & \end{array}$ & $\begin{array}{l}\text { Management crisis; } \\
\text { owe debt because of } \\
\text { promise }\end{array}$ & $\begin{array}{l}\text { Technical } \\
\text { step-up; } \\
\text { gradually } \\
\text { rebound } \\
\text { steady state }\end{array}$ \\
\hline
\end{tabular}

As an experienced senior psychological consultant, I emphasize the relationship building, empathy and observation in the qualitative research so that active and effective communication with the objectives will be carried out. The research consists of two parts. The first part is to look for two qualified and representative undergraduates; the second part is to look for heterogeneous samples based on the relative abstraction in of the interview outcome by snowball technique. There are altogether 6 undergraduates and the average length of the interview is 3 hours. The interview includes interviewee's profile, type of adversity, coping with adversity, and learning and growth.

As it is found in the interview, failure - recovery is in time sequence, which is the core of the narratives. Based on the entrepreneur's process of failure, it is divided into several important phases, which are respectively first access to startup (growth and study), new venture creation, operation crisis, low tide and bounce-back.

In the light of six interviews with student entrepreneurs, it is found that different types of entrepreneurs give different explanations of adversity, but their behaviors are in common generally. As it is discovered in the interviews, the attributes of resilience and quick recovery include happiness, subjective well-being, optimism, belief, self-control, self-decision, gratitude, tolerance, dream, hope, self-respect and ego. Especially for interviewees with active and good self-control, they are stronger in coping with problems and socializing. Their experience is concluded as: in the $1^{\text {st }}$ phase, beset with startup adversity and distress, the individual understands the current situation in a negative way and starts to doubt and deny their capacity; in the $2^{\text {nd }}$ phase, the 
individual's coping capacity with adversity varies due to different core value and ability as well as different social networking and support; in the $3^{\text {rd }}$ phase, the individual starts to interpret the adversity and explore to strengthen themselves.

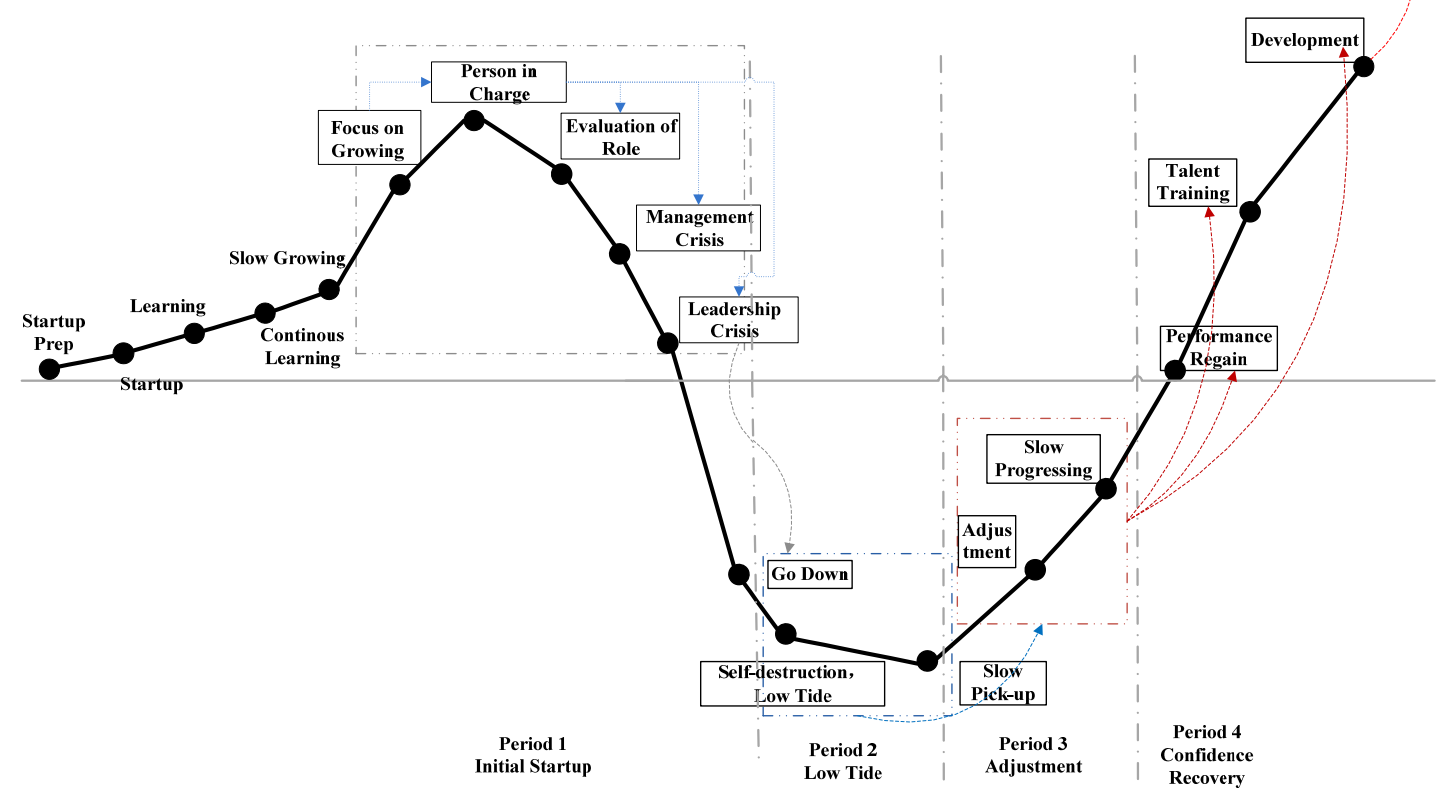

\section{Strengthening the Undergraduates' Resilience in Entrepreneurship Education}

Based on the analysis of the interview, the startup success largely depends on the strong perseverance and anti-setback ability. The undergraduates are lacking social knowledge and life experience, so distress and barriers are unavoidable in the process of new venture creation. Without strong perseverance, it is hard to move on after failure. Due to the significance of emotional factor, the failure experience is profound and long-lasting to the students. The failure may build the students' will and resilience, which affects the learning outcome and future behavior. With the conclusion of the three phases of interviews and learning model after failure, the following suggestions are put forward to the entrepreneurship educators.

\subsection{Phase 1: Frustration - Single Loop Learning Mode}

In this phase, the student entrepreneurs mostly copy the past experience and practice or directly use the skills gained from the past experience to cope with the operating problems. This direct copy or use of the past experience is called single loop learning mode. Its advantage is to tackle the urgency. But it has the weakness as well. The students haven't received systematic and professional startup training and the problems accumulate and deteriorate until the new business gets trapped. So in the $1^{\text {st }}$ phase, the higher education institutes provide relevant training and tutoring, the success rate will be improved. Garavan (1994) believes that entrepreneurship education would help developing the important entrepreneurship spirit. Entrepreneurial training plan can improve the business starters' knowledge and skills, help them reduce the risk and uncertainty, increase the survival rate of new business and improve operation performance. Most importantly, it may eliminate the students' anxiety in the beginning stage and provide them with precious resources. The student interviewees are mostly in the starting phase of new venture. For lacking of resources and external assistance, they have encountered big distress and fallen on the low tide. In reality, the higher education mostly adopts the typical way of entrepreneurship education that is the education of basic entrepreneurial theory and entrepreneurship. The training on how to get a loan, how to solve the legal issues, how to reduce the tension and anxiety is less likely to see. It is suggested that the entrepreneurship education institutes provide relevant and systemic startup training in the beginning phase of startup. The course is designed to strengthen the students' analytical ability, organizational ability, judgment, team communication and writing of startup proposal, so that the students can better understand the importance of startup planning and analysis, expand their knowledge and resources to identify startup opportunity and learn to evaluate the entrepreneurial risk. 


\subsection{Phase 2: Self-identification Learning Mode}

As it is introduced in the $1^{\text {st }}$ phase, managerial problems accumulate and deteriorate after the emergency, which is a vicious cycle leading to the failure of business. To the business newcomers, failure may cause psychological impact and make them hit the rock bottom. The educators should firstly guide them to make sense of the failure in order to rebound from the negative emotions. The students need to confront with the failure and have an in-depth analysis, so they can learn and grow from the experience (Cannon \& Edmondson, 2005). The main approach is to support social networking support to them, such as self-help team for the startup failure, which is the opportunity to interact with others, gradually change the self-awareness, and form a new framework of interpreting the external facts. Therefore, the educators at universities should focus on guiding those who fails to rebuild the self-cognition and providing effective counseling for those who have negative emotions.

\subsection{Phase 3: Reshape the Mentality - Look Ahead Mode}

Based on the strategies in the $1^{\text {st }}$ and $2^{\text {nd }}$ phase, the student entrepreneurs will gradually regain the confidence and rebuild the self-cognition, then shift the attention to the business restoration. They will have a new perspective of things and change their mindset. And the most important are the gained knowledge, belief, experience and tacit and explicit understanding after the failure, which would form into a new framework covering knowledge, belief and experience and map out the action plan for the future. This is the key of innovative entrepreneurship education at universities - enable the undergraduates to innovate to learn, to deepen the study with a changed mentality, to make sense of the failure experience, to pass the experience to those preparing for new venture or working on new business. This learning model allows the entrepreneurs to integrate the energy and transform to the subsequence startups and actions. To students, success is not the most important, but the personal value, self-capacity and personal energy improvement cultivated in the process (Patterson \& Kelleher, 2005). In other words, when students adjust and learn from the failure, gain confidence and self-cognition from the negative emotions, it is the time to develop a mature, rational and healthy mentality and immerge themselves into the work and subsequence ventures again. They learn to analyze the learning and concluding in the entire process, and proactively reflect on setting a better starting point for a new venture.

\section{Acknowledgments}

This paper is supported by Education Ministry Youth Foundation Project (15YJC630137): Research on the influence and mechanism of political gene on the rent-seeking behavior of enterprises. Run by the Characteristics of innovation projects (2015GXJK032) supported by Guangdong Leading Academic Discipling project (GD15XJY06).

\section{References}

Yang, X. (2015). Study on Entrepreneurship Education \& Innovative Talent Cultivation in Chinese Higher Education. China Higher Education Study, 1, 39-44.

Timmons, J. A. (1990). New business Opportunities: Getting to the Right Place at the Right Time Action. MA: Brick House Publishing Co. 1990.

Husted, K., \& Michailova, S. (2002). Diagnosing and Fighting Knowledge-Sharing Hostility. Organizational Dynamics, 31(1), 60-73. http://dx.doi.org/10.1016/S0090-2616(02)00072-4

Shepherd, D. A. (2003). Learning from Business Failure: Propositions about the Grief Recovery Process for the Self-Employed. Academy of Management Review, 28, 318-329. http://dx.doi.org/10.2307/30040715

Douglas, M., \& Widavsky, A. (1982). Risk and Culture. Berkeley. CA: University of California Press.

Arend, R. J. (2003). Revisiting the Logical and Research Considerations of Competitive Advantage. Strategic Management Journal, 24(3), 279-284. http://dx.doi.org/10.1002/smj.285

March, J. G., \& Shapira, Zur. (1987). Managerial Perspectives on Risk and Risk Taking. Management Science, 33(11), 1404-1418. http://dx.doi.org/10.1287/mnsc.33.11.1404

Luthans, F., Luthans, K., \& Luthans, B. (2004). Positive Psychological Capital: Going beyond Human and Social Capital. Business Horizons, 47, 45-50. http://dx.doi.org/10.1016/j.bushor.2003.11.007

Van Marrewijk, M., \& Timmers, J. (2003). Human Capital Management: New Possibilities in People Management. Journal of Business Ethics, 44(2), 171-184. http://dx.doi.org/10.1023/A:1023347715882

Adler, P. S., \& Kwon, S. (2002). Social Capital: Prospects for a New Concept. Academy of Management Review, 27, 17-40. http://dx.doi.org/10.2307/4134367

Luthans, F., \& Youssef, C. M. (2004). Human, Social and Now Positive Psychological Capital Management: 
Investing in People for Competitive Advantage. Organizational Dynamics, 33, 321-349. http://dx.doi.org/10.1016/j.orgdyn.2004.01.003

Luthans, F., \& Youssef, C. M., \& Avolio, B. J. (2007). Psychological Capital: Developing the Human Competitive Edge. Oxford, UK: Oxford University Press.

Richardson, G. E. (2002). The Metatheory of Resilience and Resiliency. Journal of Clinical Psychology, 58(3), 307-321. http://dx.doi.org/10.1002/jclp.10020

Luthans, F., Luthans, K. W., \& Luthans, B. C. (2004). Positive Psychological Capital: Beyond Human and Social Capital. Business Horizon, 47, 45-50. http://dx.doi.org/10.1016/j.bushor.2003.11.007

Scott, E. S., Maria, L. K., \& Robert, C. L. (2009). A Social Capital Theory of Career Success. Academy of Management Journal, 24(2), 219-237.

Husted, K., \& Michailova, S. (2002). Diagnosing and Fighting Knowledge Sharing Hostility. Organizational Dynamics, 31, 60-73. http://dx.doi.org/10.1016/S0090-2616(02)00072-4

Shepherd, D. A. (2004). Educating Entrepreneurship Students about Emotion and Learning from Failure. Academy of Management Learning and Education, 3(3), 274-287. http://dx.doi.org/10.5465/AMLE.2004.14242217

Garavan, T. N., \& O'Cinneide, B. (1994). Entrepreneurship Education and Training Programmes: A Review and Evaluation, Part 2. Journal of European Industrial Training, 18(8), 3-12. http://dx.doi.org/10.1108/03090599410068024

Cannon, M. D., \& Edmondson, A. C. (2005). Failing Failure to Learn and Learning Range Fail (Intelligently): How Great Organizations Put work to Innovate and Improve. Long Planning, 38(2). http://dx.doi.org/10.1016/j.lrp.2005.04.005

Patterson \& Kelleher. (2005). Resilient School Leaders-Strategies for Turning Adversity into Achievement. Alexandria, VA: Association for Supervision and Curriculum Development.

\section{Copyrights}

Copyright for this article is retained by the author(s), with first publication rights granted to the journal.

This is an open-access article distributed under the terms and conditions of the Creative Commons Attribution license (http://creativecommons.org/licenses/by/4.0/). 